\title{
Effectivity of Hand Sanitizer Cempaka Flower Extract (Michelia champaca L.) on the Growth of Staphylococcus aureus
}

\author{
Sri Jayanthi*, Nuraini, Setyoko \\ Biology Education Study Program, FKIP \\ Samudra University \\ Langsa, Indonesia \\ *srijayanthi@unsam.ac.id
}

\begin{abstract}
Hand sanitizer is an antiseptic material that can reduce the contamination of normal flora bacteria on human hands. One of the plants that contain antiseptics that can sterilize human hands from bacteria is the cempaka flower plant (Michelia champaca L). This study aims to determine the effectivity of the cempaka flower extract hand sanitizer (Michelia champaca $L$ ) on the growth of Staphylococcus aureus. This study used an experimental method with non-factorial (RAL) consisting of 5 treatments and 3 replications: $K+($ commercial HS), K- (0\%), P1 (5\%), P2 (10\%), P3 (15\%). The research result hand sanitizer extract flower (Michelia champaca $\mathrm{L}$ ) with $\mathrm{n}$ use values sig.0,003 $(p \leq 0.05)$ then there is a real effect on the treatment of hand sanitizer with flower extracts Cempaka (Michelia champaca $\mathrm{L}$ ) against the formation of inhibition zone on the media NA Staphylococcus aureus bacteria culture. The concentration of $\mathrm{P} 2$ is $10 \%$, the diameter of the inhibition zone formed is higher than the diameter of the inhibition zone formed from the commercial product hand sanitizer $P 0$ positive $0 \%$, namely $11.43 \mathrm{~mm}>10,57 \mathrm{~mm}$, the second category of inhibition zone strength is hand sanitizer. Product innovation hand sanitizer extracts of cempaka flower (Michelia champaca L) effective as antimicrobials and can be commercially viable.
\end{abstract}

Keywords—hand sanitizer, Michelia champaca, Staphylococcus aureus

\section{INTRODUCTION}

In 2020 a new type of Coronavirus disease (SARS Cov 2) has spread in every country, this disease is called Coronavirus Disease 2019 (Covid 19). The covid 19 virus is one of the diseases that is easily spread contagiously, that is it spreads quickly. Transmission of this virus can attack anyone connected to a virus carrier in social interactions [1-3]. The hand is a part of the human body where physical contact with other people often occurs during social interaction or touch with surrounding objects, so that various types of bacteria are attached to the surface of the palms. Bacteria that grow naturally on human skin include Staphylococus aureus and around $29 \%$ live on the surface of the hand [4,5]. Staphylococus aureus bacteria are gram-positive bacteria, cocci shaped with a diameter of 8.0-1 $\mu \mathrm{m}$. Staphylococus aureus is facultative and can cause toxin-type bacteria that are resistant to heating, although the bacteria are dead, the toxin can survive at $100{ }^{\circ} \mathrm{C}$ for 30 minutes [6].

Washing hands is an effort to prevent the spread of pathogenic bacteria, washing hands should use ingredients that contain antiseptics so that they can reduce and kill bacteria on the palms [7]. One of the antiseptic fluids used by the general public to clean palms is hand sanitizer. Hand sanitizers are antiseptic hand sanitizers as an alternative to washing hands without using soap and water, which aims to kill pathogenic microbes. Hand sanitizer as an antiseptic containing antibacterial ingredients functions as an inhibitor of bacterial growth on the palms [8-10].

Hand sanitizers have been widely commercialized into practical hand washing products and hignies used by the public, however, the use of hand sanitizers made from chemical solutions such as alcohol and triclosan continuously will cause skin irritation [11]. The product innovation of cempaka flower extract (Michelia champaca L) hand sanitizer is carried out as an effort to use natural ingredients that contain active compounds in plants that can inhibit microbial growth, so that the cananga flower extract hand sanitizer can be used as an antiseptic that does not cause irritation. In addition, the public wants to use natural ingredients with active ingredients in plants as health products, disease prevention and cosmetics [12]. The availability of raw material for chrysanthemum flowers which is abundant is now widely used in the health sector [13]. The results of the research by Arianti [14] showed that phytochemical screening of the cempaka flower stems with methanol containing essential oils, terpenoids, flavonoids and glycosides. The active compounds found in the cempaka plant include; alkaloids, saponins, tannins, flavonoids, glycosides, carbohydrates, proteins, and sterols, which have pharmacological activities such as antimicrobials [15]. This study aims to determine the effectiveness of cempaka flower extract hand sanitizer as an antimicrobial. 


\section{Methods}

This research method used a completely randomized design (RAL) non-factorial with 5 treatments and 3 replications: P0 $0 \%$ positive control (commercial hand sanitizer), P0 $0 \%$ negative control (hand sanitizer on gel cempaka flower extract), P1 (hand sanitizer gel 5\% flower extract cempaka), P2 (10\% cempaka flower extract gel hand sanitizer), and P3 (15\% cempaka flower extract gel hand sanitizer).

\section{A. Tools and Materials}

The tools used in this research are autoclave, petri dish, reaction tube, Erlenmeyer, drop pipette, caliper, Bunsen, volume pipette, $\mathrm{pH}$ meter, mortar and stamper. The materials used in this study were cempaka flower extract, Staphylococus aureus bacteria culture, Carbomer 940, Tri Ethanol Amin (TEA), Methyl paraben, Glycerin, 96\% ethanol, 70\% alcohol, $0.9 \% \mathrm{NaCl}$, Aquades, Natur oil cempaka., A commercial hand sanitizer product.

\section{B. Research Procedure}

1) Cempaka flower extract: Cempaka flower sample was washed, cut, then milled until smooth, then extracted using the maceration method. In the maceration stage, the cempaka flower powder was soaked with $1000 \mathrm{ml}$ methanol at room temperature for 24 hours. The immersion was filtered, then remacerated 2 times. The results obtained were concentrated with a Rotary evaporator [16].

2) Hand sanitizer gel formulation Cempaka Flower Extract: Formulation manufacture of hand sanitizer Cempaka flower extract (Michelia champaca L), can be seen in Table 1.

TABLE I. GEL HAND SANITIZER FORMUla CEMPAKA FlOWER EXTRACT (MICHELIA CHAMPACA L) [17]

\begin{tabular}{|l|l|l|l|l|l|l|}
\hline \multicolumn{1}{|l|}{ Ingredient name } & \multicolumn{1}{|c|}{ Unit } & \multicolumn{1}{|c|}{ F 1 } & F 2 & F 3 & \multicolumn{1}{|c|}{ F4 } & \multicolumn{1}{|c|}{ Function } \\
\hline $\begin{array}{l}\text { Cempaka Flower } \\
\text { Extract }\end{array}$ & Ppm & 0 & 5 & 10 & 15 & $\begin{array}{l}\text { Active } \\
\text { ingredients }\end{array}$ \\
\hline Carbomer 940 & Gram & 2 & 2 & 2 & 2 & Gel base \\
\hline TEA & Drops & 2 & 2 & 2 & 2 & Alkalizing \\
\hline Methyl parabens & Gram & 0.2 & 0.2 & 0.2 & 0.2 & Preservative \\
\hline Glycerin & Ml & 1 & 1 & 1 & 1 & Emollient \\
\hline Distilled water & Ml & $500 \mathrm{Ml}$ & $\begin{array}{l}500 \\
\mathrm{~mL}\end{array}$ & $\begin{array}{l}500 \\
\mathrm{~mL}\end{array}$ & $500 \mathrm{~mL}$ & Solvent \\
\hline
\end{tabular}

3) Zone inhibition test: Inhibition test of hand sanitizer of Cempaka flower extract (Michelia champaca L) against Staphylococus aureus by using well diffusion method. The Cempaka flower extract hand sanitizer made 5 treatments and 3 replications: $\mathrm{P} 0+$ (hand sanitizer $\mathrm{x}$ (commercial), $\mathrm{P} 0$ - (noncempaka flower extract hand sanitizer), P1 (hand sanitizer 5\% cempaka flower extract), P2 (hand sanitizer 10\% cempaka flower extract ), and P3 (hand sanitizer 15\% cempaka flower extract). The agar medium which was inoculated with Staphylococus aureus bacteria $200 \mu \mathrm{L}(1.5 \times 108 \mathrm{CFU} / \mathrm{mL})$ was made at each concentration and control, then incubated at $37^{\circ} \mathrm{C}$ for 24 hours [11]. Zone of inhibition hand sanitizer
Cempaka flower extract measured by the inhibition zone formed on each hole wells, by measuring the diameter of the zone of inhibition zone jernih. Measurement hand sanitizer Cempaka flower extracts by category Table 2 .

TABLE II. CATEGORIES OF INHIBITION ZONE [18]

\begin{tabular}{|l|l|}
\hline \multicolumn{1}{|c|}{ Diameter } & \multicolumn{1}{c|}{ Categories } \\
\hline$\leq 5 \mathrm{~mm}$ & Weak \\
\hline $6-10 \mathrm{~mm}$ & Moderate \\
\hline $11-20 \mathrm{~mm}$ & Strong \\
\hline$\geq 21 \mathrm{~mm}$ & Very strong \\
\hline
\end{tabular}

\section{Data Analysis}

Analysis of research data using One Way Analysis of Variance (ANOVA), if the conditions are fulfilled, the distribution is normal and homogeneous and if the conditions are not met, use the Kruskal Wallis test. Further test using post hoc (LSD).

\section{RESULTS AND DISCUSSION}

Data from the antimicrobial gel hand sanitizer research, the addition of cempaka flower extract (Michelia champaca $\mathrm{L}$ ) with a concentration of $15 \%$ resulted in an inhibition zone diameter of $14.3 \mathrm{~mm}$ (strong category); $10 \%$ concentration of $11.43 \mathrm{~mm}$ (strong category); $5 \%$ concentration of $8.03 \mathrm{~mm}$ (medium category); The concentration of $0 \%$ positive control was $10.57 \mathrm{~mm}$ (strong category); and $0 \%$ concentration of negative control is $0 \mathrm{~mm}$ (weak category) in Figure 3. Based on the inhibition hand sanitizer zone with the addition of cempaka flower extract (Michelia champaca L), the concentration of $10 \%$ is higher than the diameter of the inhibition zone formed compared to the diameter of the inhibition zone formed from commercial hand sanitizers. namely $11.43 \mathrm{~mm}>10.57 \mathrm{~mm}$, with (strong category).

The results of the one-way ANOVA test data analysis showed a sig. $0.003(p \leq 0.05)$, so there was a significant effect on the hand sanitizer treatment with the addition of cempaka (Michelia champaca L) flower extract on the formation of inhibition zones on Nutrient Agar (NA) media of Staphylococcus aureus bacteria culture. LSD (post hoc) further test was carried out, it was found that the treatment had a significant effect on treatment P0 - negative control with treatment $\mathrm{P} 1, \mathrm{P} 2$ and $\mathrm{P} 3$.

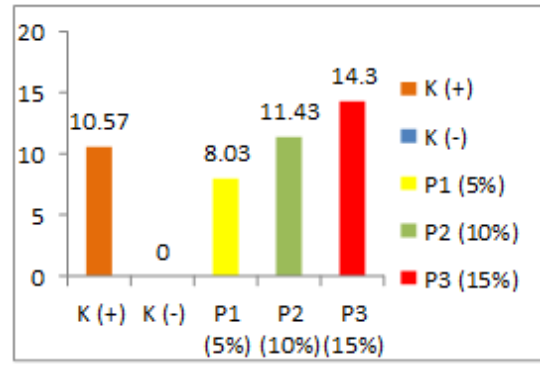

Fig. 1. Antimicrobial hand sanitizer of cempaka flower extract (Michelia champaca L) against Staphylococcus aureus bacteria. 


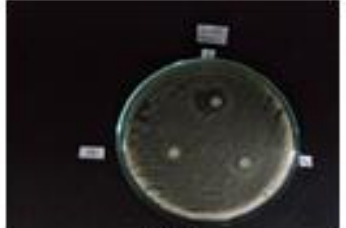

(a)

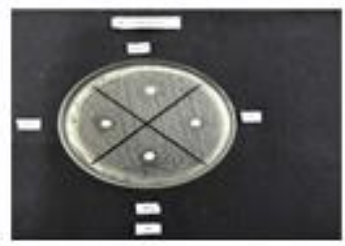

(c)

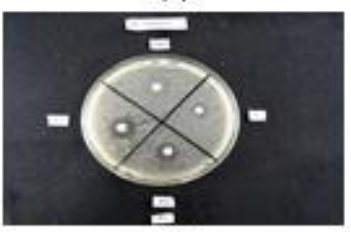

(e)

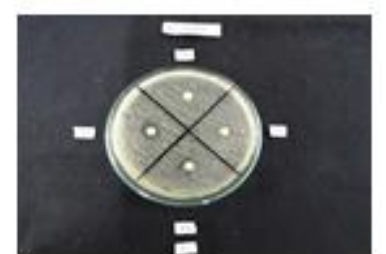

(b)

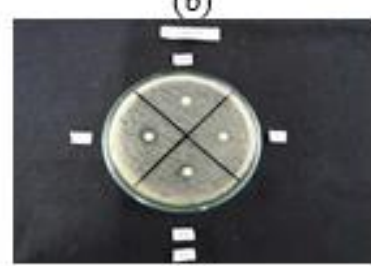

(d)
Information:

(a) $=$ P0. Positive control (Commercial HS)

(b) $=$ P0. HS Gel (Negative Control)

(c) $=\mathrm{P} 1$. HS Gel $+5 \%$ cempaka flower extract

(d) $=$ P2. HS Gel $+10 \%$ cempaka flower extract

(e) $=\mathrm{P} 3$. HS $+15 \%$ gel cempaka flower extract

Fig. 2. Inhibition zone on NA Media (Pure Culture of Staphylococcus aureus Bacteria) with hand sanitizer gel Cempaka Flower Extract (Michelia champaca $\mathrm{L})$

Positive control for P0 (+) using a commercial hand sanitizer sold in the market obtained an inhibition zone of $10.57 \mathrm{~mm}$ (strong category). The inhibition zone P0 (+) was greater than the negative control P0 (-) which used a noncempaka flower extract (Michelia champaca L) hand sanitizer gel with an inhibition zone of $0 \mathrm{~mm}$. This shows that in the negative control P0 (-) there are no active compounds contained in the hand sanitizer gel that can inhibit bacterial growth. Cempaka flower extract (Michelia champaca L) is needed in the formulation of hand sanitizer gel, because in the cempaka flower extract there are active compounds that can inhibit the growth of Staphylococcus aureus bacteria.

The results of the phytochemical screening of cempaka flower (Michelia champaca L) contained several active compounds such as tannins, flavonoids and essential oils. This active compound has the potential as an antiseptic that can inhibit the growth of Staphylococcus aureus bacteria. In line with the research results of Aditya and Ramadhania [15] cempaka flower extract (Michelia champaca L) contains active compounds such as hexane, ethyl acetate and essential oils which have antimicrobial activity, inhibition of Staphylococcus aureus bacteria by $25 \%$. Staphylococcus aureus bacteria have a polar cell wall, because the cell wall is composed of polysaccharide polymers that can dissolve in water. Chemical compounds of flavonoids and tannins are polar so they easily penetrate the cell walls of Staphylococcus aureus [19].

Treatment P1 used hand sanitizer gel with the addition of cempaka flower extract (Michelia champaca L) by $5 \%$, the inhibition zone was $8.03 \mathrm{~mm}$ (medium category). Treatment of P2 and P3 using a gel hand sanitizer with the addition of cempaka flower extract (Michelia champaca L) respectively by $10 \%$ and $15 \%$, the inhibition zone of both $11.43 \mathrm{~mm}$ (strong category) and $14.3 \mathrm{~mm}$ (strong category). It can be stated, that every increase in the concentration of cempaka flower extract (Michelia champaca L) on the hand sanitizer gel, the higher the inhibition zone of Staphylococcus aureus bacteria formed in NA medium. According to Surjowardojo [18], the antimicrobial hand sanitizer of cempaka flower extract (Michelia champaca L) shows high antibacterial activity, the higher the addition of cempaka flower extract concentration, the wider the spectrum of inhibition zone diameter is formed. The difference in inhibition zone diameter is caused by the large amount of active substance contained in the concentration.

The results of the study [20] showed that the cempaka leaf extract on the inhibition of fungal growth with a higher concentration, the stronger the inhibition zone. The extract diffuses into the bacterial cell, the higher the concentration will be directly proportional to the extract that diffuses into the bacterial cell [21]. The zone of inhibition is also influenced by other factors such as the diffusion ability of the test material in the media, the toxicity of the test material, the interaction between the components of the medium and the in vitro microenvironment conditions [22]. The $10 \%$ concentration of cempaka flower extract (Michelia champaca L) gel hand sanitizer can be recommended as an innovative product that is ready to be market. This is because hand sanitizer cempaka flower extract (Michelia champaca L) has a strong category of inhibition zone that can inhibit the growth of Staphylococcus aureus bacteria, comparable to the commercial hand sanitizer products in the market.

\section{CONCLUSION}

Hand sanitizer of cempaka extract (Michelia champaca L) at a concentration of P2 $10 \%$ inhibition zone $11.43 \mathrm{~mm}$; P3 $15 \%$ inhibition zone $14.3 \mathrm{~mm}>\mathrm{P} 00 \%$ positive control with $10.57 \mathrm{~mm}$ inhibition zone (strong category). The value of sig. $0.003(p \leq 0.05)$ means that there is a significant effect on the treatment of hand sanitizer with cempaka flower extract (Michelia champaca L) on the formation of inhibition zones on NA media for Staphylococcus aureus bacteria culture. Product innovation of cempaka flower extract hand sanitizer (Michelia champaca L) effective as an antimicrobial and commercially feasible.

\section{ACKNOWLEDGMENT}

The author thanked LPPM Samudra University for fully funding this research through a leading basic research grant in 2021 


\section{REFERENCES}

[1] N. Mona, "Concept of Isolation in Social Networks to Minimize Contagious Effects (Cases of Corona Virus Spread in Indonesia," Journal of Applied Humanities, vol. 2, no. 2, pp. 117-124, 2020.

[2] Yuliana, "Corona Virus Diseases (Covid 19) A Literature Review," Welliness And Healthy Magazine, vol. 2, no. 1, pp. 187-192, 2020.

[3] A. Susilo, R.C. Martin, W.P. Ceva, D.S. Widayat, Y. Mira, R.S Herikurniawan, S. Gurmeet, N. Leonard, J.N. Erni, C.L. Khie, W. Alvina, W. Edwin, W. Bramantya, M. Maradewi, A. Firda, O.M.J. Chyntia, and E. Yunihastuti. 2020. Coronavirus Disease 2019: A Review of Recent Literature. Indonesian Journal of Internal Medicine, 7 (1), 45 67.

[4] E.P. Rini and E.R. Nugraheni, "Inhibition Test of Various Brands of Hand Sanitizer Gel on the Growth of Escherichia coli and Staphylococcus aureus Bacteria," Journal of Pharmaceutical Science and Clinical Research, no. 01, pp. 18-26, 2018

[5] H.A. Pratami, E. Apriliana and P. Rukmono, "Identification of Microorganisms in the Hands of Medical Personnel and Paramedics at the Perinatology Unit of Abdul Moeloek Hospital, Bandar Lampung," Medical Journal of Lampung University, pp. 85-94, 2013.

[6] A.R. Costa, W.F.B. Deivid, M.R. Rosineide, M.S. Ana, M.P. Olivia, and M.B. Claudia, "Staphylococcus aureus virulence factors and disease," Formatex, vol. 1, no. 1, pp. 702-710, 2013

[7] D. Widodo, S. Milwati, and R.A.T. Diah, "The number of bacterial colonies in the palms of nurses who perform medical actions using a handscoon," Journal of Applied Nursing, vol. 3, no. 2, pp. 70-79, 2017.

[8] P. Srikartika, N. Suharti, and E. Anas, "The Active Inhibition Capability of Several Trademarks of Hand sanitizer against the growth of Staphylococcus aureus," Andalas Health Journal, vol. 5, no. 3, pp. 540541,2016

[9] S.M. Situmeang and T. Sembiring, "The Effectiveness of Hand Sanitizers in Killing Germs on Hands," AnLabMed Journal, vol. 1, no. 1, pp. 6-11, 2016

[10] N.A. Meiliawati, N. Pramanti, L. Amalia, G.A. Salsabila, R. Puspito, and D. Retnoningrum, "Hand sanitizer of trembesi leaf extract (albizia saman (jacq.) Merr), grape aroma as an antiseptic," Diponegoro Journal of Medicine, vol. 7, no. 1, pp. 359-365, 2018

[11] D. Chuniasih, M. Anggraini and S. Marcellia, "Utilization of Avocado Seed Waste (Persea Americanasemen) in Hand Sanitizer Gel For Staphylococcus Aureus Bacteria Inhibitor," Malahayti Journal of Pharmacy, vol. 3, no. 1, pp. 53-65, 2020.
[12] R. Sari and D. Isadiartuti, "Study of the Effectiveness of Hand Antiseptic Gel for Betel Leaf Extract (Pipe betle Linn)," Indonesian Information Magazine, vol. 17, no. 4, pp. 163-169, 2006.

[13] V.A. Fachurdin, Mahfud and L. Qadriyah, "Extraction of Cempaka Flower Oil by Hydrodistillation and Hydrodistillation Method with Air Flow,” Engineering Journal ITS, vol. 5, no. 2, pp. 232-235, 2016.

[14] N.P. Ariantari, N. Rustini, and L. Tumewu, "Antimalarial Activity of Cempaka Stem Bark Extract on Plasmodium falciparum 3D7," Indonesian Journal of Pharmaceutical Sciences, vol. 11, no. 1, pp. 66-69, 2013.

[15] W.A. Aditya and Z. Ramadhania, "Article Reviews: Content and Pharmacological Activities of Cempaka Kuning Plants (Michelia Champaca Linn.)," Farmaka, vol. 16, no. 3, pp. 10- 19, 2018.

[16] Bustanussalam, D. Apriasi, S. Eka, and J. Dadang, "Antibacterial Effectiveness of Betel Leaf Extract (Piper Betle Linn) Against Staphylococcus Aureus Atcc 25923," Fitofarmaka: Pharmaceutical Scientific Journal, vol. 5, no. 2, pp. 58-64, 2015.

[17] Ningsih, D.R. Purwati, Zusfahir and A. Nurdin, "Hand Sanitizer Methanol Extract of Arumanis Mango Leaves (Mangifera indica L.),' ALCHEMY: Journal of Chemical Research, vol. 15, no. 10, pp. 10-23, 2019.

[18] P. Surjowardojo, T. Susilorini, and G.R. Sirait, "Inhibition of smoked apple skins manalagi (malus sylvestrs mill.) On the growth of staphylococcus aureus and pseudomonas sp. Causes of mastitis in dairy cows," Journal of Tropical Livestock, vol. 16, no. 2, pp. 40-48, 2015.

[19] Septiani, E.N. Dewi, and I. Wijayanti, "Antibacterial activity of Seagrass (Cymodocea rotundata) extract against Staphylococcus aureus AND Escherichia coli," Fisheries Science: Indonesian Journal of Fisheries Science and Technology, vol. 13, no. 1, pp. 1-6, 2017.

[20] S. Purwantisari, "Activity Test of Cempaka Leaf Extract (Michelia champaca) on the Control of Fungal Growth and Bacteria that Causes Wilt in Tomato Plants BIOMA," vol. 7, no. 1, pp. 1-8, 2005

[21] Oktabimasakti, Antibacterial effectiveness of antiseptic gel of methanol extract of tanjung stem bark (mimusops elengi 1.) Against Escherichia coli bacteria and staphylococcus aureus. Thesis, Tanjung Pura University: Pontianak, 2015.

[22] A. Candrasari, M. Romas, M. Hasbi, and O.R. Astuti, "Antimicrobial power test of ethanol extract of red betel leaf (piper crocatum ruiz and pav.) On the growth of staphylococcus aureus atcc 6538, eschericia coli atcc 11229 and candida albicans atcc 10231 in vitro," Biomedics, vol. 4 , no. 1 , pp. $9-16,2012$ 